\title{
Reference
}

Andersen, S., Bailey, J., Karup-Møller, S. et al. 1973: Research projects on the Ilímaussaq alkaline intrusion, South Greenland. Rapp. Grgnlands geol. Unders. 55, 38-40.

Institut for Petrologi, University of Copenhagen,

Øster Voldgade 10,

1350 Copenhagen $K$.

\section{HYDROGEOCHEMICAL INVESTIGATIONS ON RIVER WATER IN WEST, SOUTH AND EAST GREENLAND}

\section{Gert Asmund}

Hydrogeochemical investigations have been concerned with the analysis of heavy metals dissolved in stream and river water. The concentrations of metals like $\mathrm{Cu}, \mathrm{Pb}, \mathrm{Ni}, \mathrm{Cr}$, and $\mathrm{Cd}$ are however usually below the level of detection by commonly used water analysis methods. For this reason, and to overcome some of the problems connected with the transportation of water from Greenland to Copenhagen, i.e. contamination of the samples by the container or absorption of metals on the container surface, a new method of analysis was developed two years ago at the Danish Atomic Energy Commission's Research Establishment, Risø.

\section{The method}

Small nylon bags containing heavy metal selective ion exchangers, $1 \mathrm{~g}$ weight, are placed in the streams for a period of not less than 14 days. This is sufficient time for the ion exchanger and the water to be brought into equilibrium. The bags are then collected and analysed for the desired elements. The concentration factor is in the range of 100000 , which means, that water containing $0.1 \mathrm{ppb}$ dissolved metal yields an ion exchanger with $10 \mathrm{ppm}$, which is easy to analyse by optical spectrography. The main theoretical problem is to determine the concentration factor and to achieve reasonable reproducibility.

\section{Field work}

In the summer of 1972 the method was tested for the first time at various places in Greenland, when Survey personnel working essentially on other projects undertook to place ion exchange samplers in rivers and lakes (see e.g. Andersen et al., 1973). In the summer of 1973 the work was continued. The author visited the Narssaq area in South Greenland where a large programme was embarked 
Table 3. Preliminary results of metal contents in river water at localities in West, South and East Greenland

\begin{tabular}{|c|c|c|c|c|c|c|c|c|c|c|}
\hline & \multirow{2}{*}{$\begin{array}{l}\text { Number of } \\
\text { sample } \\
\text { sites }\end{array}$} & \multicolumn{5}{|c|}{$\begin{array}{l}\text { Metal content in ion exchangers } \\
\text { relative to Taseq river }\end{array}$} & \multicolumn{4}{|c|}{$\begin{array}{l}\text { Electrode measurements } \\
\text { direct on water }\end{array}$} \\
\hline & & $\mathrm{Cu}$ & $\mathrm{Pb}$ & $\mathrm{Ni}$ & $\mathrm{Zn}$ & $\mathrm{Cr}$ & $\mathrm{Cd}$ & $\underset{\mathrm{ppm}}{\mathrm{F}}$ & $\begin{array}{c}\mathrm{Ca} \\
\mathrm{ppm}\end{array}$ & $\begin{array}{l}\text { conductivity } \\
\mu \text { MHD }\end{array}$ \\
\hline $\begin{array}{l}\text { South Greenland } \\
\text { Ilimaussaq area }\end{array}$ & 13 & 1.2 & 5.2 & 0.6 & 2.4 & 1.1 & 1.0 & 1.86 & 0.78 & 60 \\
\hline $\begin{array}{l}\text { West Greenland } \\
\text { Fiskenæsset area }\end{array}$ & 5 & 2.9 & 1.9 & 10 & 0.2 & 4.0 & 1.8 & 0.05 & 0.50 & 11 \\
\hline $\begin{array}{l}\text { East Greenland } \\
\text { Tunnelelv at } \\
\text { Mesters Vig }\end{array}$ & 3 & 15 & $>100$ & 2.1 & $>20$ & 1.1 & 3.5 & 0.45 & 20.5 & 180 \\
\hline $\begin{array}{l}\text { Hjørnedal river, } \\
\text { Gåseland, } \\
\text { Scoresby Sund area }\end{array}$ & 4 & 27 & 1.5 & 72 & $<0.2$ & 2.9 & 4.0 & 0.20 & 7.2 & 60 \\
\hline $\begin{array}{l}\text { 'Geigen Elv', } \\
\text { SE Milne Land, } \\
\text { Scoresby Sund area }\end{array}$ & 1 & 35 & 0.8 & $>2500$ & $<0.2$ & 3.0 & 14 & 0.03 & 7.4 & 55 \\
\hline
\end{tabular}


Results

Some results are shown in table 3 in which the metal contents in ion exchangers are given relative to the content in ion exchangers that were placed in the 'standard river' - that flowing from Taseq lake, near Narssaq in South Greenland. To convert to absolute $\mathrm{ppb}$ the relative values have to be multiplied with the concentrations in Taseq river which have not yet been determined.

Some interesting correlations between water content and bedrock can be gleaned from the results. The river water in the Ilimaussaq area is seen to be characterised by high fluoride, zinc and lead contents - products of the Ilímaussaq alkaline intrusion. The known chromite occurrences in the Fiskenæsset area can be recognised in the slightly higher $\mathrm{Ni}$ and $\mathrm{Cr}$ contents, but the Ca-rich anorthosites which form a dominant part of the Precambrian basement in that area, are not reflected in the water analyses.

In East Greenland, at Mesters Vig, where Tunnelelv drains the area where the exhausted lead-zinc mine is situated, the ion exchangers were filled with lead and zinc to over the upper detection limit. It is somewhat surprising that cadmium is not present in a higher amount in the water. The two rivers sampled in the Scoresby Sund area show rather high $\mathrm{Cu}, \mathrm{Cr}$ and $\mathrm{Cd}$, and extremely high $\mathrm{Ni}$ values, particularly the 'Geigen Elv', i.e. the river north-east of Mudderbugt in southeastern Milne Land. Unfortunately only one sample from this latter locality was available for analysis.

\section{Reference}

Andersen, S., Bailey, J., Karup-Møller, S., Løkkegaard, L., Rose-Hansen, J., Steenfelt, A. \& Sørensen, H. 1972: Research projects on the Ilimaussaq alkaline intrusion, South Greenland. Rapp. Grønlands geol. Unders. 55, 38-40.

\section{AIRBORNE GEOPHYSICAL SURVEY IN CENTRAL EAST GREENLAND}

\section{Bjarne Leth Nielsen and Hans Christian Larsen}

In 1971 aeroradiometric work was carried out in the Scoresby Sund region (see Nielsen, 1972; Løvborg \& Nielsen, 1973). In 1973 an airborne geophysical programme was begun in East Greenland between $72^{\circ}$ and $76^{\circ} \mathrm{N}$. The main topics of this programme were a regional radiometric reconnaissance coupled with an airborne magnetic survey. The greatest importance was attached to the radiometric project, which is a collaboration between GGU and the Danish Atomic Energy Commission's Research Establishment, Ris $\varnothing$.

GGU and Ris $\varnothing$ supplied 7 and 6 personnel respectively and these were joined 